\title{
Oyo State Students and Malaria Management
}

\author{
Abdulfatah Ibrahim ${ }^{I^{*}}$, Oluwadamilola Aminat Oluberu ${ }^{2}$, Saheed Opeyemi Usman ${ }^{3}$, Nafisat Oladayo Akintayo-Usman ${ }^{4}$, \\ Ibiwumi Nafisat Isola ${ }^{5}$, Titilope E. Ojediran ${ }^{6}$, Tonubari Fadero ${ }^{7}$
}

\begin{abstract}
Background: Malaria is a vector-borne infectious disease caused by eukaryotic protist of genus Plasmodium and transmitted by female Anopheles mosquitoes. Those living mainly in the world's poorest countries are at risk of malaria as it is more endemic in the tropical and sub-tropical regions. Malaria spread has been linked to environmental changes, malaria vector dynamics, host immune status and individual or community factors such as the socio-economic status, knowledge of malaria and the protective behaviour. The objective is to assess knowledge, perceptions and practice of malaria management among non-medical students of higher institutions in Oyo State, Nigeria. Methods: An open-ended structured questionnaire was administered consecutively to 1198 consenting non-medical students by interviewer at various higher institutions. The crosssectional survey questionnaire comprised sections on socio-demographic data, knowledge about causes of malaria and knowledge about malaria management and practice. Results: The mean age (SD) was 21.7 (5.9) years. Five hundred and thirty respondents $(44.2 \%)$ are male while 668 respondents $(55.8 \%)$ are female. One thousand and seventy-seven students $(89.9 \%)$ reported that malaria can be cured. Seventy-four students $(6.2 \%)$ understand malaria prophylaxis to be a preventive treatment for malaria and 211 students (17.6\%) said Artemisinin-based Combination Therapies (ACTs) are the most effective among the drugs they have used to treat malaria. Conclusion: Non-medical students have relatively reasonable knowledge about malaria management and practices, although, certain aspects are still not well understood, probably due to the scope of their educational curricula. Hence, there is need to intensify malaria public enlightenment programs and promote affordable treatment.
\end{abstract}

Keywords: Malaria, student, mosquito, management.

\section{Oyo Eyaleti Öğrencileri ve Sitma Yönetimi}

Genel Bilgiler: Sıtma; ökaryotik tek hüçreli plazmidyum cinsinin sebep olduğu, vektör kaynaklı bulaşıcı bir hastalık ve dişi anopheles türü sivrisineklerle geçiş gösterir. Tropikal ve subtropikal bölgelerde daha yaygın olduğu için dünyanın en yoksul ülkelerinde yaşayanlar sıtma riski altındadır. Sıtma hastalığının yayılması, çevresel değişiklikler, sıtma vektörü dinamikleri, konakçının bağışıklık durumu ve sosyo-ekonomik durum, sıtmaya ilişkin bilgi ve korunma davranışı gibi bireysel ve toplumsal etmenlere bağlıdır. Amaç: Nijerya, Oyo Eyaleti'nde tıp dışındaki yüksek öğrenim öğrencilerinin sıtma hastalığı yönetimine ilişkin bilgi, algı ve uygulamalarının değerlendirilmesidir. Yöntem: Açık uçlu yapılandırılmış anket çeşitli yüksek öğrenim kurumlarında, tıp öğrenimi dışındaki öğrencilerden anketin uygulanmasını kabul eden 1198 kişiye görüşmeci tarafından uygulanmıştır. Kesitsel anket çalışmasındaki bölümler; sosyo-demografik veri, sıtma nedenlerine ilişkin bilgi ve sıtma hastalığı ve uygulmalarına ilişkin bilgiyi kapsamaktadır. Bulgular: Katılımcıların ortalama yaşı $21.7 \pm$ 5.9 yıl idi. Altıyüz altmışsekiz katılımcı (\% 55.8) kadın iken 530 katılımcı (\% 44.2) erkektir. Bin yetmiş yedi öğrenci $(\% 89,9)$ sitmanın tedavi edilebilir olduğunu bildirdi. Yetmiş dört öğrenci (\% 6.2) sıtma hastalığı profilaksisinin, sitma için önleyici tedavi olduğunu anladığı ve 211 öğrenci (\%17,6), Artemisinin - tabanlı kombinasyon tedavileri (AKT)' nin sitma hastalığı tedavisinde kullandıkları ilaçlar arasında en etkin olduğunu belirtti. Sonuç: Tıp öğrenimi dışındaki öğrencilerin sıtma hastalığı yönetimi ve uygulamalarına ilişkin bilgileri görece uygun (nispeten makul) olmasına karşın bazı yönlerin hala iyi anlaşılamamış olması belki de eğitim programlarının kapsamından kaynaklanıyor olabilir. Bu nedenle, halkı aydınlatma programlarını yoğunlaştırmaya ve uygun fiyatlı tedavileri geliştirmeye ihtiyaç vardır.

Anahtar Kelimeler: Sitma, öğrenci, sivrisinek, yönetim

\section{Received/Geliş tarihi: 20.10.2015, Accepted/Kabul tarihi: 28.02.2016}

${ }^{1}$ Babcock University Teaching Hospital, Ilishan-Remo, Nigeria, ${ }^{2}$ Mecure Healthcare Limited, Ibadan, Nigeria, ${ }^{3}$ Department of Clinical Laboratory, Equitable Health Access Initiative, Akure, Nigeria, ${ }^{4}$ Department of Medical-Surgical Nursing, Osun State School of Nursing, Osogbo, Nigeria, ${ }^{5}$ Department of Biochemistry, Federal University of Technology, Akure, Nigeria, ${ }^{6}$ Institute of Child \& Adolescent Health, University of Ibadan, Ibadan, Nigeria, ${ }^{7}$ Africare Nigeria, Lekki, Lagos, Nigeria

*Address for Correspondence / Yazışma Adresi: Sahed Opeyemi Usman Department of Clinical Laboratory, Equitable Health Access Initiative, Akure, Nigeria.E-mail: senatorhopsy@yahoo.com

Ibrahim A, Oluberu OA, Usman SO, Akintayo-Usman NO, Isola NI, Ojediran TE, Fadero T. Oyo State Students and Malaria Management, TJFMPC, 2016;10(3): 126-130.

DOI:10.21763/tjfmpc.33433 


\section{INTRODUCTION}

Malaria, one of the most important causes of morbidity in the world, is a vector-borne infectious disease caused by a eukaryotic protist of the genus Plasmodium. The disease is transmitted by female Anopheles mosquitoes which carry infective sporozoite stage of Plasmodium parasite in their salivary glands. ${ }^{[1]}$ Malaria spread has been linked to environmental changes, malaria vector dynamics, host immune status and individual or community factors such as the socio-economic status, knowledge of malaria and the protective behavior. ${ }^{[2]}$ The burden of malaria or estimated cases of malaria is reported worldwide to be between 350 550 million, with over $80 \%$ occurring in Africa. ${ }^{[3]}$ The treatment of malaria depends on the severity of the disease. Uncomplicated malaria may be treated with oral medications. The most effective strategy for Plasmodium falciparum infection is the use of artemisinins in combination with other antimalarials, which reduces the ability of the parasite to develop resistance to any single drug component. ${ }^{[3]}$ A study on the knowledge and the preventive strategies of malaria among migrant farmers showed that $64 \%$ of respondents said malaria can lead to death, $85 \%$ stated malaria manifests with fever, headaches/body pains and 59\% know about and are using prophylactic malaria drugs. ${ }^{[4]}$ Furthermore, the research on knowledge, attitudes and practices about malaria and its control in Tanzania, reported that artemether-lumefantrine was the most common antimalarial therapy used and health facilities were the first option for malaria treatment as said by $47.3 \%$ respondents. ${ }^{[5]}$

In Colombia, a study published in 2014 on knowledge, attitudes and practices of malaria, stated that $89.3 \%$ respondents said malaria can be cured using tablets. Respondents stated fever, headache and chills were stated $52.8 \%, 17.8 \%$ and $15.0 \%$ respectively as malaria symptoms. ${ }^{[6]}$ The findings from a study on the attitude, knowledge and practices regarding malaria prevention and treatment showed that the respondents had partially correct understanding of malaria transmission, treatment and prevention. ${ }^{[7]}$ The outcome of another research work on the knowledge and practices on malaria treatment measures in Abeokuta, Nigeria revealed $65 \%$ of the participants had three to four episodes of malaria per year while $27 \%$ of respondents stated general body pain and headaches as symptoms associated with malaria. ${ }^{[8]}$ Another research on knowledge, attitude and management practices on malaria in Anambra State, Nigeria, stated that $40.1 \%$ of respondents visited hospital for malaria treatment, $57 \%$ of respondents said malaria is caused by malaria parasite, $50.9 \%$ used ACTs in malaria treatment and $27.4 \%$ stated fever, chills, vomiting, body ache and headache as symptoms of

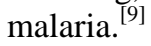

Inadequate knowledge, misconceptions about the transmission, perception and management of malaria has been reported among various strata of the society and this can adversely affect malaria control measures. These misconceptions and inadequate knowledge were reported to have prompted several studies in this research area as evident in research work carried out in Tanzania, Colombia as well as Abeokuta and Anambra State of Nigeria respectively. ${ }^{[6,7,8,9]}$ This study is therefore designed to assess knowledge, perceptions and practice of malaria management among non-medical students of higher institutions in Oyo State, Nigeria. The scientific benefit of this study is thus to find out if there are truly misconceptions about this disease and its management in this group of people, as assessed in a 2011 study among migrant farmers. ${ }^{[5]}$

\section{MATERIALS AND METHODS}

\section{Study Site/Subject Selection/Study Design}

The cross-sectional survey study utilizing both qualitative and quantitative method of data collection was conducted at various higher institutions across Oyo State, Nigeria. Participation was voluntary. Informed consent was obtained from the participants. It was however ensured that all questionnaires in each class, each department and each institution were administered only once to avoid dual response. The structured questionnaire was administered consecutively to 1198 consenting non-medical students by interviewer in each of the institutions. Simple random sampling was used to randomly select the required number of participants (students not in any medical related field) till the required number of willing participants is recruited. The questionnaire contained sections including sociodemographic data, knowledge about malaria management, knowledge about causes of malaria and practice of malaria management. The data collected through the questionnaire were statistically analyzed using Statistically Package for the Social Sciences (SPSS) for windows version 20.0 software. Frequency counts were generated for all variables and statistical tests of significance was performed with chi square test. Significance was fixed at $\mathrm{P}<0.05$ and highly significant if $\mathrm{p}<0.01$.

\section{Sample Size}

Sample size calculation was done using $95 \%$ confidence interval, 0.02 precision and prevalence rate. A 2011 study on the malaria morbidity in Akure revealed that $87.32 \%$ of the sampled populations in Akure Township have experienced malaria. ${ }^{[10]}$ The formula for sample size when population is more than 1000 is:

$\mathrm{n}=\mathrm{Z}^{2} \mathrm{PQ} / \mathrm{d}^{2}{ }^{[11,12]}$

$\mathrm{n}=\mathrm{Z}^{2} \mathrm{PQ} / \mathrm{d}^{2}$

Where:

$\mathrm{n}=$ minimum sample size,

$\mathrm{Z}=$ standard normal deviation at $95 \%$ confidence interval which is 1.96 ,

$\mathrm{d}=$ degree of precision (taken as 0.02 ), 
$\mathrm{P}=$ proportion of the target population or prevalence of malaria

(estimated at $87.32 \%$ which is $87.32 / 100=0.8732$ ),

$\mathrm{Q}=$ alternate proportion $(1-\mathrm{P})$ which is $1-0.8732=0.126$

$\mathrm{n}=\underline{(1.96)^{2}(0.8732)(0.1268)}=1063$

$$
\text { ( } \frac{(0.02)^{2}}{2}
$$

\section{RESULTS}

\section{Socio-Demographic Data}

A total of 1198 consenting higher institution students located within the state participated in the study. The mean age (SD) was 21.7 (5.9) years. Eight hundred and ninetynine $(75.0 \%)$ of the students were ages $18-25$ years. There were $530(44.2 \%)$ male respondents and $668(55.8 \%)$ female respondents. Eight hundred and two (66.9\%) of the students practice Christianity with 396 (33.1\%) being Muslims. Table 1 show the socio-demographic data of the respondents.

\begin{tabular}{|l|l|l|l|}
\hline \multicolumn{2}{|l|}{ Table 1. Sociodemographic data } \\
\hline S/No & DEPARTMENT & N & $\%$ \\
\hline 1 & Economics & 151 & $12.6 \%$ \\
\hline 2 & Mass Communication & 128 & $10.7 \%$ \\
\hline 3 & Business Administration & 85 & $7.1 \%$ \\
\hline 4 & Social Studies & 64 & $5.3 \%$ \\
\hline 5 & Computer Science & 59 & $4.9 \%$ \\
\hline 6 & Crop Production Technology & 55 & $4.6 \%$ \\
\hline 7 & Music & 45 & $3.8 \%$ \\
\hline 8 & Geography & 45 & $3.8 \%$ \\
\hline 9 & Agricultural Extension Management & 45 & $3.8 \%$ \\
\hline
\end{tabular}

\section{Knowledge About Causes of Malaria}

Seven hundred and fifteen $(59.7 \%)$ respondents stated that malaria parasite belongs to the genus Plasmodium while $153(12.8 \%)$ disagree, with others deciding not to respond. Of those that know about Plasmodium and the various species that cause malaria infection in human, $160(13.4 \%)$, $24(2.0 \%), 17(1.4 \%)$ and $10(0.8 \%)$ listed Plasmodium falciparum, Plasmodium vivax, Plasmodium malariae and Plasmodium ovale respectively. One hundred and fortyeight (12.4\%) respondents reported that Plasmodium falciparum is the most common species that cause malaria infection. One hundred and ninety-one (15.9\%) of the respondents stated microscopy as the most commonly used laboratory method to detect malarial parasite. Seventy-four $(6.2 \%)$ of the respondents understand malaria prophylaxis to be a preventive treatment of malaria. Table 2 shows the knowledge about management of malaria.

\begin{tabular}{|l|l|l|l|l|l|l|}
\hline \multicolumn{1}{|c|}{ Table 2. Knowledge about management of malaria } \\
\hline & \multicolumn{2}{|c|}{ Yes } & \multicolumn{3}{c|}{ No } & \multicolumn{2}{c|}{ No Response } \\
\cline { 2 - 7 } & $\mathrm{N}$ & $\%$ & $\mathrm{~N}$ & $\%$ & $\mathrm{~N}$ & $\%$ \\
\hline $\begin{array}{l}\text { Malaria can be } \\
\text { cured }\end{array}$ & 1077 & 89.9 & 29 & 2.4 & 92 & 7.7 \\
\hline $\begin{array}{l}\text { Malaria can } \\
\text { lead to death }\end{array}$ & 988 & 82.5 & 104 & 8.7 & 106 & 8.8 \\
\hline $\begin{array}{l}\text { There is vaccine } \\
\text { against malaria }\end{array}$ & 246 & 20.5 & 736 & 61.5 & 216 & 18.0 \\
\hline
\end{tabular}

Table 3. Relationship between academic level with availability of vaccine against malaria

Availability of vaccine against malaria

\begin{tabular}{|c|c|c|c|c|}
\hline & Yes & No & $\begin{array}{l}\text { No } \\
\text { Response }\end{array}$ & Total \\
\hline \multicolumn{5}{|l|}{ Academic Level } \\
\hline First Year & 135 & 41 & 47 & 223 \\
\hline Second Year & 112 & 42 & 29 & 183 \\
\hline Third Year & 147 & 40 & 33 & 220 \\
\hline Fourth Year & 57 & 26 & 22 & 105 \\
\hline Fifth Year & 29 & 9 & 7 & 45 \\
\hline Ordinary National Diploma (OND) & 144 & 48 & 48 & 240 \\
\hline Higher National Diploma (HND) & 112 & 40 & 30 & 182 \\
\hline Total & 736 & 246 & 216 & 1198 \\
\hline
\end{tabular}

The relationship between academic level and availability of vaccine against malaria is not statistically significant at $\mathrm{P}<0.05$. 


\section{Practice of Malaria Management}

In the last six months, $53(4.4 \%)$ students reported they had been diagnosed of malaria infection. Majority (more than two-thirds) of the students listed signs and symptoms of malaria to include headache, fever, vomiting, nausea, pain, chills, loss of appetite, body weakness etc. At least one sign/symptom was mentioned by most of the students, which shows high level of understanding in this regard.

During the last episode of malaria, $193(16.1 \%)$ students used ACT mainly artemether and lumefantrine while $73(6.1 \%)$ used Non-ACT mainly sulfadoxinepyrimethamine (Fansidar), with certain 22 students $(1.8 \%)$ reported to have used chloroquine. Most of the drugs used by the students for the last bout of malaria, were received from the school clinic and patent medicine store. The number of the subjects were $190(15.9 \%)$ and $452(37.7 \%)$ respectively. On the other hand, 40 (3.3\%) students reported self-medication. According to two hundred and eleven students (17.6\%) ACTs, mainly referred to as Coartem/Lonart, are the most effective drugs they have used to treat malaria. $35(2.9 \%)$ said that chloroquine, and 118 students $(9.8 \%)$ claimed that non-ACT such as Fansidar is the most effective malaria drug.

In summary, the average knowledge score, calculated by the total number of correct responses by respondents divided by the total number of available options/questions, was $46 \%$. In the study methodology we classified the knowledge score as poor knowledge when it is below or equal to $39 \%$, as fair knowledge when it is between $40-49 \%$, average knowledge for the score of $50-$ $59 \%$, good knowledge for the scores between $60-69 \%$ and excellent knowledge when it is $70 \%$ and above. Based on this rating, the students have fair knowledge about the management of malaria as well as the practice of the disease management. Table 3 shows the relationship between academic level and availability of vaccine against malaria.

\section{DISCUSSION}

According to our findings, $15.9 \%$ stated microscopy as the most commonly used laboratory method to detect malarial parasite. This could be due to widespread use of antigenbased Rapid Diagnostic Tests (RDTs) in most laboratories/clinics. Our study outcome showed $92.4 \%$ of the respondents stated that malaria can be cured. This is similar to the 2014 Colombian study, which reported $89.3 \%$ respondents said malaria can be cured by using tablets. ${ }^{[6]}$ The finding that $86.1 \%$ of the respondents stated malaria can lead to death is in contrast to that reported by a research published in 2011 that revealed $64 \%$ of respondents stated malaria can lead to death. ${ }^{[4]}$

Our research showed that $6.2 \%$ of the students understand malaria prophylaxis to be a preventive treatment of malaria is in contrast to that reported by the a study in published in 2011which stated 59\% know about and are using prophylactic malaria drugs. ${ }^{[4]}$ Also, our finding that more than two-thirds of the students listed signs and symptoms of malaria to include headache, fever, pain, chills, loss of appetite, body weakness etc, probably is as a result of the fact that they have experienced some of them previously in course of having malaria infection. This finding is corroborated by the 2011 study that reported $85 \%$ of respondents stated malaria manifests with fever, headaches and body pains. ${ }^{[4]}$ It is, however, not in agreement with another Colombian research that stated $52.8 \%, 17.8 \%$ and $15.0 \%$ of respondents indicated fever, headache and chills as malaria symptoms ${ }^{[6]}$ and the outcome of another 2008 research which showed $27 \%$ of participants stated general body pain and headaches as symptoms associated with malaria. ${ }^{[8]}$ These findings do not concur with the outcome of another study that indicated $27.4 \%$ of respondents stated fever, chills, vomiting, body ache and headache as symptoms of malaria. ${ }^{[9]}$

Our findings also revealed that $4.4 \%$ students reported they had been diagnosed of malaria infection in the past six months. This is in contrast to another research that reported $65 \%$ of participants had three to four episodes of malaria per year. ${ }^{[8]}$ Most of the drugs used by the students for the last episode of malaria were received from the school clinic (15.9\%) and patent medicine store (37.7\%) respectively. This finding does not correspond with another research that reported $40.1 \%$ respondents visited hospital for the treatment of malaria ${ }^{[9]}$, as well as the 2010 study carried out in Tanzania, which found out that health facilities were the first option for malaria treatment as said by $47.3 \%$ respondents. ${ }^{[5]}$ During the last diagnosis of malaria, $16.1 \%$ of the students used ACT mainly artemether and lumefantrine, while $6.1 \%$ used Non- ACT mainly sulfadoxine-pyrimethamine (Fansidar), with certain $1.8 \%$ reported to have used chloroquine. This is related to the findings of the Tanzanian research that reported artemetherlumefantrine was the most common antimalarial therapy used. ${ }^{[5]}$ It is also in line with another study outcome that showed $50.9 \%$ used ACTs in malaria treatment, which was the commonest. ${ }^{[9]}$ Of participants, $17.6 \%$ naming ACTs as the most effective drugs used to treat malaria. This may be because of ACTs are gradually becoming widespread in various clinics and patent medicine stores, and perhaps, they are the most common antimalarial drugs available in recent years, as non-ACTs are largely no longer recommended. Also, it could be due to resistance issues that have made other previously used drugs to be less popular in recent times. This study rated the students as having fair knowledge about the management of malaria as well as the practice of the disease management. This is similar to the 2010 Indian research that indicated that the respondents had partially correct understanding of malaria transmission, treatment and prevention. ${ }^{[7]}$

Major aspects of the knowledge, perceptions and practice of malaria management that the students seem to 
have done poorly include species of Plasmodium that cause malaria infection in human, the most common species that cause malaria infection, the most commonly used laboratory technique to detect malaria parasite, information about malaria prophylaxis, most effective antimalarial drugs currently used, among others, as substantial number of students have some knowledge gap in these areas. These were largely responsible from the final fair knowledge outcome. This could be due to the fact that majority of the students either have such knowledge gap because they do not have a science-based background or have not given more attention to the issue of malaria infection, especially as their courses curricula do not cover the field.

\section{CONCLUSION}

In conclusion, non-medical students have fairly reasonable knowledge about malaria treatment/management and practices, although, certain aspects such as information about malaria prophylaxis, species of Plasmodium that cause malaria infection in human, the most common species that cause malaria infection, the most commonly used laboratory technique to detect malaria parasite, among others, are still not well understood, probably due to the scope of their educational curricula. Hence, there is need to intensify malaria public enlightenment programs and promote affordable treatment.

\section{REFERENCES}

1. Okwa OO, Soremekun BM, Adeseko O, Raheem AM. Artisans and Traders' knowledge, attitude and practices of malaria control in selected areas of Lagos, Nigeria. Glob Adv Res J Med\& Med Sci 2012;1(3):068-074.

2. Kinung'hi, SM, Mashauri F, Nwanga JR, Nnko SE, Kaatano GM, Malima R. Knowledge, attitudes and practices about malaria among communities: Comparing epidemics and non-epidemic prone communities of Muleba District, Northwestern Tanzania. BMC Pub Health 2010; 10:395.

3. Guidelines for the treatment of malaria, $2^{\text {nd }}$ edition. World Health Organization (WHO). 2010; ISBN13:978-92-4-154792-5.

4. Adegun JA, Adegboyega JA, Awosusi AO. Knowledge and the preventive strategies of malaria among migrant farmers in Ado Ekiti Local Government Area, Nigeria. Am J Sci \& Industr Res 2011; ISSN:2153 - 649.

5. Mazigo HD, Obasy E, Mauka W, Manyiri P, Zinga M, Kweka HJ, et al. Knowledge, attitudes and practices about malaria abd its control in Rural Northwest Tanzania. Malar Res \& Treat 2010; Article ID 794261.

6. Forero DA, Chaparro PE, Vallejo AF, Benavides Y, Gutierrez JB, Arevalo-Herrera M, et al. Knowledge, attitudes and practices of malaria in Colombia. Malar $\mathbf{J}$ 2014; 13:165.
7. Sabin LL, Rizal A, Brooks MI, Singh MP, Tuchman J, Wylie BJ, et al. Attitude, knowledge and practices regarding malaria prevention and treatment among pregnant women in Eastern India. Am J Trop Med Hyg $2010 ; 82$ (6):1010-1016.

8. Sam-Wobo SO, Akinboroye T, Anosike JC, Adewale B. Knowledge and practices on malaria treatment measures among pregnant women in Abeokuta, Nigeria. Tanzan J Health Res 2008;10(4):226-231.

9. Iwueze MO, Ezugbo-Nwobi IK, Umeanaeto PU, Egbuche CM, Anaso CI. Knowledge, attitude and management practices on malaria: A case study of Amansea Awka North Local Government Area of Anambra State, Nigeria. The Bioscientist 2013;1(1):32-38.

10. Ayeni AO. Malaria morbidity in Akure, Southwest, Nigeria: Temporal observation in a climate change scenario. Trends App Sci Res 2011; 6:488-494.

11. Fisher RA. Statistical methods for research workers. Oliver and Boyd 1954; ISBN 0-05-002170-2.

12. Daniel WW. Biostatistics: A Foundation for Analysis in the Health Sciences $10^{\text {th }}$ ed. 2013. 